Article

\title{
Sustainable Production Clauses and Positioning in the Global Value Chain: An Analysis of International Investment Agreements (IIA) of the ICT Industry in Developing and Developed Markets
}

\author{
Qi Meng ${ }^{1}$, Muhammad Mohiuddin ${ }^{2, *}$ iD and Yuliang Cao ${ }^{3, *}$ \\ 1 School of Economics and Management, Zhejiang University of Science and Technology, \\ Hangzhou 310023, China; 116017@zust.edu.cn \\ 2 Department of Management, Université Laval, Quebec, QC G1V 0A6, Canada \\ 3 School of Management, Tianjin University of Technology, Tianjin 300384, China \\ * Correspondence: muhammad.mohiuddin@fsa.ulaval.ca (M.M.); ylc0081@aliyun.com (Y.C.)
}

check for

updates

Citation: Meng, Q.; Mohiuddin, M.; Cao, Y. Sustainable Production Clauses and Positioning in the Global Value Chain: An Analysis of International Investment Agreements (IIA) of the ICT Industry in Developing and Developed Markets. Sustainability 2022, 14, 2396.

https://doi.org/10.3390/su14042396

Academic Editors: Attila Bai and

Bruce Morley

Received: 18 November 2021

Accepted: 17 February 2022

Published: 19 February 2022

Publisher's Note: MDPI stays neutral with regard to jurisdictional claims in published maps and institutional affiliations.

Copyright: (C) 2022 by the authors. Licensee MDPI, Basel, Switzerland. This article is an open access article distributed under the terms and conditions of the Creative Commons Attribution (CC BY) license (https:// creativecommons.org/licenses/by/ $4.0 /)$.

\begin{abstract}
Positioning in the global value chain (GVC) reflects the level and kinds of value creation of a firm or industry. The value creation can be on the upstream or downstream of the value chain. This study explores the effects of sustainable production clauses on the economic and physical positioning of information and communication technology (ICT) firms in the global value chain (GVC). We examined 2107 international investment agreements (IIA), signed by 54 countries that represent $70 \%$ of the global investment agreements. The empirical results show that the sustainable production intensity clauses in the IIAs have a significant impact on the positioning of ICT's in the GVC. However, the degree of impact on the economic scale of participation and physical location in the GVC differs. The heterogeneity test shows that the sustainable production intensity clauses of IIAs between developed and developing countries affect positively and significantly the physical and economic locations in the GVCs. This is less significant while the IIAs are signed between the developed markets. These findings demonstrate that countries should consider sustainable production principles and responsible business conducts while signing the IIAs, and ensure their implementation while participating in the GVCs. This process can enhance value creation by moving towards higher value creation activities within the GVC.
\end{abstract}

Keywords: ICT industry; value chain position; sustainable production intensity; international investment agreements; developed and developing markets

JEL Classification: F6; F13; F15; D57

\section{Introduction}

The global value chain (GVC) allows multinational enterprises in optimizing their resource allocations as well as access to required resources on a competitive basis [1-3]. The GVC started with Europe and America as the manufacturing center and gradually grew into a global production network (GPN) integrating emerging, developing, and developed markets across the globe [4]. Countries like China emerged as a formidable laborintensive low-tech industrial factory floor with a strong, affordable, and diligent workforce. With strong policy support and investment in infrastructure, R\&D, and technology, many emerging countries are moving-up-the value ladder within the GVC. With the rise of tradein-value-added (TiVA) products and services, most countries and companies can participate in the global value chains with their respective comparative advantages. There are different levels of activities that take place in the value chain network with the aim of creating a web of best performers. The relative contribution of any firm or country to the GVC and its value creation depends largely on the positioning of the firm in the value chain [5]. 
Activities in both extremes of the value chain create the highest amount of value [6]. On the other hand, activities in downstream or close to the final demand create higher value than the activities in the middle of the value chain such as manufacturing activities. That is why it is important that firms understand their positioning in the global value chain and how they can move to the higher value ladder that can create increased value and keep the competitiveness of the firm or industry in the long term. The GVC production process is highly competitive and volatile. Multinational companies (MNCs) continuously evaluate the competitiveness of their suppliers from the developing markets. By focusing on the positioning of activities in the higher value-creating segment/s of the value chain through continuously upgrading the capabilities by investing in R\&D and human capital, suppliers from the developing countries can improve their competitiveness and keep their relevance to their clients from the developed markets. This paper addresses the positioning of the ICT industry in the GVC and how the sustainable production clauses in the IIA contribute to the positioning in the GVC. The following sections present a literature review and hypothesis development (Section 2), research methodology (Section 3), results and discussions (Section 4), and the conclusion (Section 5).

\section{Global Value Chain, Sustainable Production Clauses in IIA, and Positioning}

The global value chain integrates producers of different components that we need to assemble for producing a complete product. The level of value creation depends on the type of activities that each of these producers of different components contributes to the production process of a complete good. Production of any goods needs the contributions from several actors starting from the R\&D till the production of a complete good as well as bringing that product to the final consumer. There are many actors and interactions among those actors.

\subsection{Smiling Curve, GVC Components, and Their Positioning}

The smiling curve as the Figure 1 represents graphically the different components of the GVC.

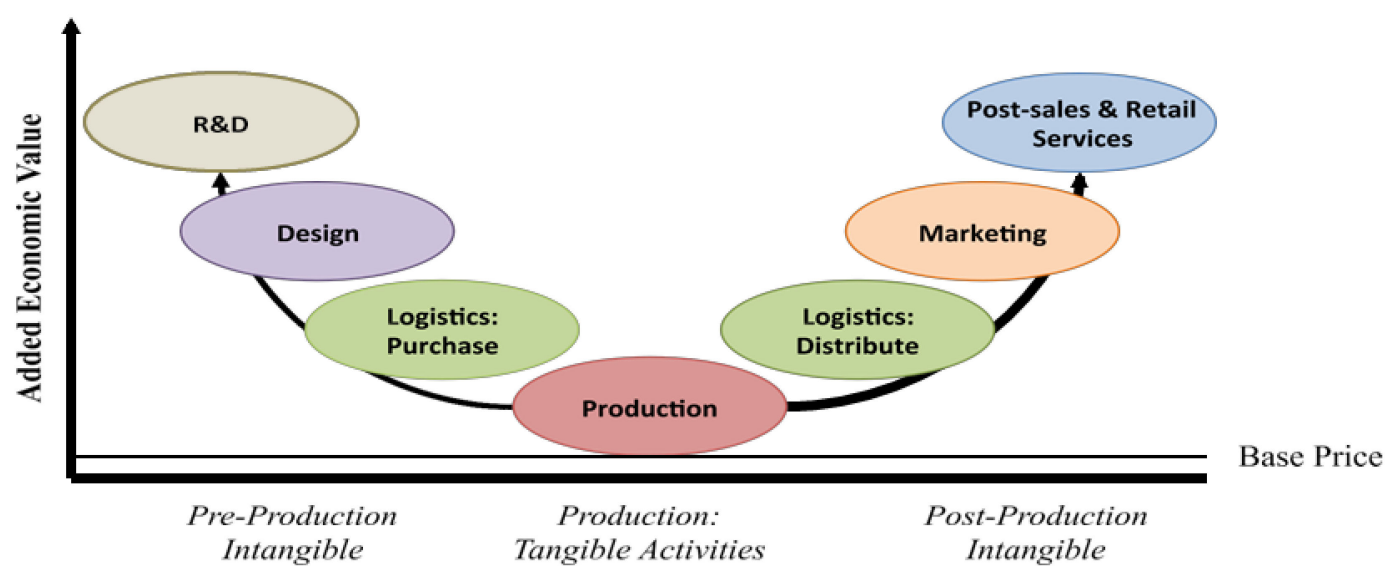

Value-Adding Activities

Figure 1. Smiling Curve. (Adapted from $[2,7,8]$ ).

The GVC consists of multiple stages of production; each of which has a value-added effect, with two stages in different countries or regions [9]. The types of GVCs include 'spider-like' and 'snake-like' structures [10]. Regardless of the GVC shape, the possibility of slicing up the value chains and dispersing them through the cross-border production networks leads to a more refined global division of labor, and specialization that contributes to higher productivity and more benefits. GVCs allow resources to flow between countries and sectors, and to the most productive uses at all stages of production. It creates a network of best performers that allows the integrator firm to achieve sustainable competitive ad- 
vantage (SCA). Under the 'super-specialization' interpretation of the GVC, the traditional determinants of international trade (factor endowments, geographic location, economic growth, market size) are naturally related to the degree to which countries and industries are integrated into the GVC. However, these traditional factors might not have similar effects to the trade-in-value-added production flows and need to be supplemented by skills level, innovation environment, and pro-active public policy supports among others. The level of value creation in the GVC depends on the positioning of the firm, sector, or the country in the value chain [6]. The activities in the two extreme positions of the value chain such as R\&D, conception, and design as well as logistics and branding and marketing are knowledge and capital intensive that create the most important values of the GVC [6].

As the main actor of the GVC, MNCs pursue profit maximization by placing production links in different locations worldwide and conducting global business activities to form a GVC that maximizes their net profit. The distribution of the chain and the links between the enterprises that perform the production activities of the chain create a global production network (GPN) through the process. The higher participation with the GVCs provides opportunities for job creation, knowledge transfer, and economic growth. It helps to develop production facilities, procure required components locally and use local raw materials. The process can overcome the challenges of the resource gap and create an economy of scale for participating firms in the GVC. At the same time, each location within the GVC does not create the same value. The upstream manufacturing value chains mostly involve the raw materials and the production of primary intermediate components and are relatively far from the final demands. A country is specializing in upstream (downstream) activities when it imports a low (high) share of intermediate components and exports a high (low) share of intermediate exports to third countries' exports [11]. The extreme end of upstream intangible activities such as research and designing and conception create higher value than the other components. The downstream value chains produce highvalue-added components and close to the final demands drive firms and countries to focus on specialization [12]. Within the downstream of the value chain, the extreme ends create higher value than other parts of the downstream value chain. There are thus two types of positioning in the GVC. First, the scale of participation to the GVC, which is called economic positioning, and then, the location within the GVC, either at the upstream, downstream, or bottom stream or at both extremes of the value chain, which is often considered as the physical location in the GVC. Both positions together create the overall positioning of the firms on the GVC. Different inputs in the global value chains create different levels of value. There are different kinds of policy supports required for an effective configuration of different units of the value chain. That is why we need to understand both the economic and the physical positioning of the firms in the GVC. Depending on the local context, firms participate either in the upstream or downstream of the value chain. Understanding the impact of sustainability clauses on the positioning of the ICT industry in the GVC can improve the organizational and institutional policy formulation process for maximizing value creation. We will analyze the IIAs and explore how the sustainability clauses in the IIA influence the positioning of the ICT in the GVC.

However, participation in a GVC does not necessarily translate into a broader and more positive development process. Moreover, it can have negative effects pertaining to the environment, labor, and other social issues. Some groups may benefit from GVC participation more than others, but the other groups can be negatively impacted. Participation in GVCs without taking into consideration the social and environmental issues may increase inequality, worsen working conditions, and degrade environmental resources [13].

Currently, the international community emphasizes the importance of sustainable production and consumption process to concur with the growing awareness of consumers and the UN sustainable development goals (SDG). Academia and policymakers have discussed the inclusion of public interest norms in international investment agreements (IIAs). They have emphasized the integration of environmental, health, and human rights issues into the global economic agenda such as trade and investment agreements of multilat- 
eral or regional entities. This is to ensure the triple bottom line (TBL) sustainability by demonstrating the inter-connectedness of economies, societies, and environments [14-16]. Therefore, developing countries must determine what type of foreign direct investment (FDI) they would attract through IIAs as the effects of IIAs on investment fields differ. If the government regards IIAs as an effective tool to attract quality FDI for sustainable economic development, they must study its heterogeneous effects and include sustainable production principles in their decision-making process on incoming FDI. It can have negative effects, such as environmental pollution while promoting the economic growth and employment opportunities of host countries. With the continuous increase of stringent environmental quality requirements in developed markets, the compliance of environmental regulations is increasingly becoming challenging. These regulations force many pollution-intensive companies with FDI to enter developing countries with relatively loose environmental regulations, making them a 'pollution refuge', and posing a pollution threat to the host country. FDI can have many impacts on the socio-economic arena, including the labor market and wages, through wage distortion and the proportion of labor income. Presently, most countries are committed to sustainable development goals (SDG) and responsible business conducts. IIAs can be influenced by the domestic policy-making process through 'national treatment', 'fair and just treatment', and other provisions. Some studies have found that the policies of a country or region affect individual behavior, and have spillover effects within a certain range. By introducing the sustainable production clauses in the IIA, it can have a huge influence on the outcome of those investments in the emerging markets. Those clauses can improve the attraction of quality FDI and help local suppliers to improve their service provisions and, over time, upgrade the value ladder. Some studies show that Mexico's main motivation for joining the North American Free Trade Agreement (NAFTA) was to increase the inflow of cross-border investment [17] and gain knowledge and technology to increase their participation in the North American value chain. Studies have shown that service and investment-related clauses in regional trade agreements (RTAs), such as service trade liberalization, investment, intellectual property protection, and other non-trade clauses, can affect FDI implementation. There is a positive correlation between FDI and intellectual property clauses in RTAs [18].

Participants in the GVC continuously try to improve their positioning in higher value-added activities to achieve the objective of moving up the value ladder. The more a firm or country contributes to the higher value-added activities, the more that firm or country creates economic opportunities for the home country and contributes to the economic and social development of that country $[19,20]$. To determine what impact will the sustainable production clauses in the bilateral investment agreements have on the positioning in the GVC, it is highly desirable to have an in-depth understanding of the level of value creation. To test the impact of sustainable production and responsible business conduct provisions in IIAs on the position of the GVC, this study explores the sustainable production and responsible business clauses in the IIAs, using bilateral FDI data from the International Monetary Fund (IMF)'s CDIs (coordinated direct investment survey). The scale of participation of the ICT industry is relatively high and highly dispersed along the GVC. Therefore, we study the impact of sustainable production clauses in IIA on the positioning in the GVC of the ICT industry. The sustainable production clauses in IIAs can affect positively the positioning in the GVC. The level of economic development and the disparity of the economies; developed vs. developing; might have a heterogeneous influence on the participation in the GVC.

\subsection{Rise of Sustainable Development Goals (SDGs) and the GVC}

The World Commission on Environment and Development [21] proposed the concept of sustainable development, which is defined as a development model that does not harm the ability of future generations to meet their needs while meeting the needs of the current generation. Under the framework of the sustainable development concept, the United Nations (UN, 1982) published Agenda 2030, and established the 'action plan for 
sustainable development goals (SDGs) worldwide' [22]. In 2016, a total of 175 countries signed the Paris Agreement and established a series of complete and transparent operational mechanisms under the framework of the UN Convention on Climate Change [23]. Today, SDGs have become a social and environmental standard to guide human action and are integrated into the study of individual, social, and environmental impacts [24,25]. Hence, applied economic science has derived several theoretical branches, such as green, climate change, low-carbon economies, etc. Sustainable development practices have been extended to applied economics, including investment and trade. Under the joint promotion of many international organizations and economists, related research and discussions on sustainable investment have been proliferated. Sustainable production clauses can influence favorably the effective and efficient use of tangible and intangible resources of firms. This process can lead toward the optimization of environmental and economic performance [26]. The augmented emphasis on sustainability can push for innovations and can transform the production process, and improve the efficiency and effectiveness of using all factors of production. Production and process innovation along with an inflow of knowledge and technology and know-how can drive the gradual shift from the extraction of raw materials and basic pollution embedded in manufacturing towards the higher value-added components. Authors [27] found that sustainable production principles lead to an environmental and economic gain in the textile industry. Author [28] found that the supplier SMEs can develop sustainability-oriented innovation (SOI) with the support from client firms in the GVC framework. Authors [29] found that sustainable production principles contribute to green innovation in the manufacturing industry. Sustainability clauses in the IIAs are likely to contribute to the economic benefits for participating firms in the GVC. Thus, the sustainability clauses can force manufacturing companies to innovate and become eco-friendly and subsequently help the firms to focus on the high-value creating activities in the GVC.

\subsection{Hypothesis Development: Sustainability Clauses in the IIAs and Positioning in the GVC}

The GVC framework enables MNCs to develop a network of best performers by integrating suppliers from developed, emerging, and developing markets. The impact of the GVC on the economy, society, and environment is becoming increasingly significant. While promoting global trade, investment inflow, and economic development, MNCs bring at the same time some environmental and social problems, such as environmental degradation to the developing host countries. Therefore, international organizations such as G20/OECD, ILO, and UN have developed corporate governance principles with a view to supporting economic efficiency, sustainable growth, and financial stability [30]. These organizations have successively recommended measures to regulate and guide corporate behaviors including the declaration on social policies, the global contract, and the international standard for social responsibility [30].

Social responsibility guidelines and initiatives of multilateral organizations for MNCs aim to solve the negative effects of globalization and promote sustainability. MNCs that adopt responsible business conducts act in an economic, environmental, social, and governance (ESG)-friendly sustainable manner. Regardless of the country or region, corporations must respect human rights, operate legally, and conduct responsible business activities in compliance with international standards, such as the UN Business and Human Rights Guidelines or the OECD Guidelines for Multinational Corporations. Both guidelines emphasize that companies can make positive voluntary contributions to sustainable development and inclusive growth while avoiding and addressing negative impacts. Promoting responsible business behavior is beneficial for the competitive advantage of firms. It can actively enhance the company's image, boost employee morale, and improve labor productivity. By incorporating social responsibility, companies can mitigate risks, innovate products and services, strengthen brands, and increase profitability.

This study examined 2107 sample agreements, covering investment agreements signed by 54 countries, which is more than $70 \%$ of the total number of global investment agree- 
ments, including 2094 bilateral agreements and 13 multilateral agreements [31]. The study categorized sustainability clauses into four areas: Environment, Labor, Human rights, and Anti-corruption. Before 2000, there were relatively few IIAs that included sustainable development and responsible business conduct related clauses. Recently, however, there has been a significant shift towards the proper application of sustainability principles. Among the 2183 IIAs signed between 2000 and 2020, more than 83\% of IIAs have included at least one sustainable production-related clause out of the above-mentioned four areas of responsible business conducts. Among the four areas of sustainable production clauses, the frequency of environmental protection is the highest. In bilateral investment agreements, $76.4 \%$ of agreements included environmental protection, and $62.4 \%$ of investment treaties included labor clauses. The proportions of human rights and anti-corruption clauses were $46.5 \%$ and $39.2 \%$, respectively. Sustainable production and responsible business conduct clauses can appear in different sections of the IIAs.

In the GVC, MNCs excel in core technologies, R\&D, conception and design, brands, and marketing channels, and control the high value-added links [7,32]. If developing countries want to increase their value addition in the GVC, they need to continuously develop their capability and actively participate with superior productivity and resources both tangible and intangible, and attract quality investments from MNCs. According to the theory of international investment, cross-border investments are for efficiency or cost-saving, market-driven, and/or resource-driven motivations [33]. Although developing countries are rich in natural and labor resources, they lack capital, technology, managerial expertise, and knowledge of international markets. To attract MNCs with FDIs, developing countries may reduce social compliance standards and implicitly allow foreign investors to lessen environmental standards. Therefore, many MNCs have different levels of labor and environmental standards depending on the market they operate in. It depends on the socioeconomic and institutional infrastructure of the host country rather than the standard these MNCs follow in their home market which is usually the developed economies. Through the sustainable production clauses in the IIAs, international organizations, home, and host country governments have strengthened the supervision of MNCs. Participants in cross-border production and trade aspire to achieve their goals from the GVC without relaxing the health, safety, and environmental standards that safeguard public interests. If participation in the GVC activities adversely affects the public interest, the country can implement regulatory measures. Though increased supervision can increase production costs, it accelerates the transformation of the production processes and innovates more efficient production processes. The stringent policies help to invest in high-technology and other capital goods leading to a cleaner production system. In the GVC, this shift is translated by moving from basic manufacturing of raw materials at the bottom of the smiling curve, to moving towards the upstream or downstream segments for higher value capturing and environment-friendly production systems. The pollution generating raw material processing and assembly links are shifted towards (cleaner) intermediate products and other links, while the final processing/ finishing and assembly links are shifted to countries or regions with flexible policies towards ESG. Based on the above discussion, this study proposes the following hypotheses:

Hypothesis 1: The intensity of sustainability clauses in the IIAs affects a country's position in the GVCs towards higher value-added production activities, regardless of its previous position.

The IIAs cover a wide range of areas, and there are a complex set of clauses. For example, UNCTAD's IIA drawing project contains several sustainable production clauses, and some are reflected in bilateral investment agreements. The investment agreements signed by countries contain significant differences in terms of a sustainable production concept and its applications, which impacts differently the scale and scope of participation of countries in the GVC. Moreover, the IIAs are also designed based on the socio-economic and institutional infrastructure prevailing in the participating countries. Sustainable production 
clauses help manufacturing firms in the developing market to organize their activities by respecting environmental, social, and economic norms. Public policy-makers become more conscious about this issue and promote sustainable production. Therefore, sustainable production clauses have less impact when signing the agreement between the two advanced economies as they already have a well-established institutional infrastructure to deal with the sustainable production issues. IIAs between the developed economy MNCs and developing country suppliers might have the highest impact as the IIA clauses can ensure sustainable production and transfer of sustainable business practices to the developing and emerging markets through the relocation of production facilities to these later countries along with technology transfer, know-how, and superior business management practices. As countries have different levels of socio-economic and institutional infrastructures, we therefore propose:

Hypothesis 2: The sustainability clauses in the IIAs have different levels of effects for countries with different levels of socio-economic and institutional infrastructures; developed vs. developing countries participating in the GVC.

\section{Research Methodology}

We have chosen 12 variables presented in Table 1 . Ten of those variables have a positive sign. We predict that if those variables increase in volume and/or intensity; that has a positive impact on positioning in the GVC. Only the variable "geographical distance" has a negative sign which means we predict this variable has the opposite impact on the positioning in the GVC. The other variable, the global value chain location index is neutral. The definition of all the explanatory variables are provided in Table 1.

\subsection{Empirical Model}

To empirically evaluate the impact of the sustainable development clauses on the positioning of the ICT industry in the GVC, the gravity model is used to set the following equation:

$$
\text { GVC_p } \mathrm{P}_{i t}=\beta_{0}+\beta_{1} \mathrm{SDE}_{\mathrm{it}}+\beta_{\mathrm{i}} \mathrm{X}_{\mathrm{it}}+\gamma_{\mathrm{i}}+\varepsilon_{\mathrm{it}}
$$

where GVC_p represents the GVC position of the ICT industry, and SDE represents the intensity variable of the sustainable development clauses in the IIA signed between the partner economies. $X$ is the control variable, $\beta$ is the corresponding regression coefficient vector, which includes the virtual variables in the gravity equation model (i.e., the two economies have the same boundary, language, distance, etc.), $\gamma$ is the fixed effect term of economy $i$, and $\varepsilon$ is the error term.

\subsection{Dependent Variable: Positioning in the Global Value Chain}

The existing literature has two streams of research about a country's position in the GVC. The first is the GVC position index [34], which is the difference between the forward and backward participation of a country's specific industry in the GVC by comparing it as an intermediate product. The relative importance of suppliers and clients is used to measure the positioning in the GVC. The second measure is the 'physical location' [35] and uses the upstream index to determine a country's production task/s in the GVC [36]. From the production to final consumption, products require the input of specific services such as transport, logistics, marketing, branding, and so on. The closer the input is to the final consumption, the closer the embedded position is to the downstream of the value chain. Figure 1 shows the principal components of a global value chain and qualitatively informs the different levels of value creation in the GVC. Hence, research on measuring the positioning of the GVC has become important for academia. In this study, the economic position and the upstream index of the 'physical position' are used to measure the embedded position in the GVC'. 
Table 1. Description of Variables.

\begin{tabular}{ccc}
\hline $\begin{array}{c}\text { Variable } \\
\text { Abbreviation }\end{array}$ & Variable Name & Predicted \\
Sign
\end{tabular}

The length of the final product production chain initially put into the $\mathrm{j}$ sector by the $\mathrm{i}$ sector is as follows:

$$
\operatorname{plvy}_{\mathrm{ij}}=\frac{\mathrm{v}_{\mathrm{i}} \sum_{\mathrm{k}}^{\mathrm{n}} \mathrm{b}_{\mathrm{ik}} \mathrm{b}_{\mathrm{kj}} \mathrm{y}_{\mathrm{j}}}{\mathrm{v}_{\mathrm{i}} \mathrm{b}_{\mathrm{ij}} \mathrm{y}_{\mathrm{j}}}
$$

Therefore,

$\operatorname{plv}_{\mathrm{i}}=\sum_{j}^{n}\left(\frac{\mathrm{v}_{\mathrm{i}} \mathrm{b}_{\mathrm{ij}} \mathrm{y}_{\mathrm{j}}}{\sum_{\mathrm{k}}^{\mathrm{n}} \mathrm{v}_{\mathrm{i}} \mathrm{b}_{\mathrm{ik}} \mathrm{y}_{\mathrm{k}}} \times \frac{\sum_{\mathrm{k}}^{\mathrm{n}} \mathrm{b}_{\mathrm{ik}} \mathrm{b}_{\mathrm{kj}}}{\mathrm{b}_{\mathrm{ij}}}\right)=\sum_{j}^{n}\left(\frac{\sum_{\mathrm{k}}^{\mathrm{n}} \mathrm{b}_{\mathrm{ik}} \mathrm{b}_{\mathrm{kj}} \mathrm{y}_{\mathrm{j}}}{\sum_{\mathrm{k}}^{\mathrm{n}} \mathrm{b}_{\mathrm{ik}} \mathrm{y}_{\mathrm{k}}}\right)=\mathrm{x}_{\mathrm{i}}^{-1} \sum_{\mathrm{j}}^{\mathrm{n}} \sum_{\mathrm{k}}^{n_{\mathrm{ik}}} \mathrm{b}_{\mathrm{k}} \mathrm{b}_{\mathrm{kj}} \mathrm{y}_{\mathrm{j}}=\mathrm{x}_{\mathrm{i}}^{-1} \sum_{\mathrm{k}}^{n} \mathrm{~b}_{\mathrm{ik}} \mathrm{x}_{\mathrm{k}}=\sum_{\mathrm{k}}^{\mathrm{n}} \mathrm{g}_{\mathrm{ik}}$

Summary to final product sector level:

$$
\mathrm{ply}_{\mathrm{j}}=\sum_{\mathrm{i}}^{\mathrm{n}}\left(\frac{\mathrm{v}_{\mathrm{i}} \mathrm{b}_{\mathrm{ij}} \mathrm{y}_{\mathrm{j}}}{\sum_{\mathrm{k}}^{\mathrm{n}} \mathrm{v}_{\mathrm{k}} \mathrm{b}_{\mathrm{kj}} \mathrm{y}_{\mathrm{j}}} \times \frac{\sum_{\mathrm{k}}^{\mathrm{n}} \mathrm{b}_{\mathrm{ik}} \mathrm{b}_{\mathrm{kj}}}{\mathrm{b}_{\mathrm{ij}}}\right)=\sum_{\mathrm{i}}^{\mathrm{n}} \mathrm{v}_{\mathrm{i}} \sum_{\mathrm{k}}^{\mathrm{n}} \mathrm{b}_{\mathrm{ik}} \mathrm{b}_{\mathrm{kj}}=\sum_{\mathrm{k}}^{\mathrm{n}} \mathrm{b}_{\mathrm{kj}}
$$

To the whole closed economic system:

$$
\left(\mathrm{uB} \hat{\mathrm{Y}} \mathrm{u}^{\prime}\right) /(\mathrm{uY})=(\mathrm{uBY}) / \mathrm{GDP}=(\mathrm{uX}) / \mathrm{GDP}
$$

The length of the production chain includes the forward and backward production chain lengths. The length of the forward production chain is the total output driven by the value-added unit, and the length of the backward production chain is the total output driven by the final demand. The total production chain length of the system is the ratio of total output to the GDP, and the production chain length is the sum of the value-added unit divided by the final product's footprint in each sector involved. PLv_GVC is defined as the forward length of the GVC of a country or industry, and PLy_GVC is defined as the backward length of the GVC of a country or industry, that is, the upstream degree.

$$
\begin{aligned}
& P_{\text {PL_GVC }}^{s}=\frac{X_{\text {v_GVC }}}{V_{-} G_{V C}} \\
& \text { PLy_GVC } \\
& =\frac{X_{\text {y_GVC }}}{\text { Y_GVC }^{s}}
\end{aligned}
$$

The formula of the location in the GVC is as follows:

$$
\text { GVC_Pos }^{\mathrm{s}}=\frac{\text { PLy_GVC }}{\text { PLv_GVC }}
$$

Based on the World Input-Output Database (WIOD), we calculated the economic and physical position of the ICT industry of various countries participating in the GVC, to 
verify the impact of the sustainable development clauses on the position of a country's ICT industry in the GVC.

\subsection{Explanatory Variables: Sustainable Production Clauses in the IIAs}

According to the classification of investment terms in the IIA Mapping Project, ten terms related to sustainable production and responsible business conduct were selected to construct sustainable production intensity.

(A) Right to regulate: The preface of the IIA includes provisions for supervision rights (e.g., independent supervision, policy space, and flexibility to ensure the introduction of new rules). Other chapters include reservations and terms of the supervision.

(B) Promotion of sustainable production: The term sustainable production is included in the foreword of the IIA, and the environmental aspects (e.g., biodiversity and climate change) are included. Clauses related to health safety and the environment, and clauses that do not lower the standard to attract FDI (related to environment and/or labor standards) are included.

(C) Social investment special clauses: In the foreword of the IIA, the provisions on social investment (e.g., human rights, labor, health, corporate social responsibility, and poverty reduction) have been included, and labor standards, social responsibility, and corruption are included in other chapters.

This study uses WIOD to construct the GVC position and upstream index of the ICT industry. Sustainable production clauses in IIAs are scored according to the following rules: if any clause in the above sub-items is included in the bilateral investment agreement, the dummy variable of the corresponding clause is assigned a value of 1 , and we assigned ' 0 ' otherwise. Finally, the scores of the 10 types of dummy variables are added and recorded as the total score of the functional variables of sustainable production and responsible business behavior. The highest score is 10 , and the lowest score is 0 .

\subsection{Control Variables}

The dummy variables in the gravity equation model include whether the two economies have a common boundary (BOUN) and language (LANG). The distance variable (DIST) measures the weighted distance of economies $\mathrm{i}$ and $\mathrm{j}$ by natural logarithm. These data were obtained from the CEPII GeoDist database.

Foreign investment variables include foreign direct investment (FDI) and outward direct investment (ODI). When using the gravity equation model for the empirical test of FDI, it is necessary to perform a logarithmic transformation on FDI data to reduce the skewness of the distribution and use FDI data to perform inverse hyperbolic sine transformation:

$$
\ln \mathrm{FDI}_{\mathrm{it}}=\ln \left(\mathrm{FDI}_{\mathrm{it}}+\sqrt{\left(\mathrm{FDI}_{\mathrm{it}}\right)^{2}+1}\right.
$$

where FDI is the original data of FDI. Market size (MSIZ) is an important factor affecting FDI flow since a larger market provides an increasing efficiency of returns to scale. The logarithm of GDP calculated by economy $j$, according to the price and exchange rate in 2000 , is used to measure market size. The institutional quality variable (DGI) is used. Since some provisions on sustainable production and responsible business conduct in IIAs are nominal commitments, the analysis of the contents of the provisions on these does not represent the actual evaluation results of the implementation of the provisions by host markets. Whether the host markets implement sustainable production and responsible business conduct provisions depends on the judicial system, administrative system, and compliance of socio-economic and environmental standards; hence, it depends on the institutional quality of each economy. The global governance indicators (WGI) released by the World Bank are used to reflect the institutional quality of the economy.

In addition to the control variables involved in the gravity model, based on studies $[9,37]$, the factors affecting the positioning of firms in the GVC also include R\&D investment, human capital, and the import and export of intermediate products. 
The level of science and technology is still the primary productive force in an economy. It is the purpose and driving force for a country to participate in the GVC. Both the value added and the way of participating in the GVC reflect the level of a country's technological infrastructure. Countries with a higher level of technology generally have higher valueadded capabilities, higher downstream participation, and higher value chain control. The technological level of a country can be improved through R\&D investment. The level of R\&D investment indicates a country's emphasis on technological investment and its reserve capacity for technological upgrading. This is expressed as the ratio of R\&D investment to GDP. The data comes from the World Bank database, and some missing data are filled by estimation.

The development of technology is inseparable from people, and technological innovation and technological progress are more of the result of human capital with high-quality skills and competence, and value-added potential. The role of human capital is reflected in product production and can be expressed by labor efficiency, that is, the output level of a unit of labor. This is expressed as a country's public education expenditure as a percentage of GDP. The data comes from the World Bank database, and all missing data are estimated and filled by annual growth rates.

Trade and investment are two ways to participate in the global economy, so trade is also a way to affect a country's status in the GVC. As the scale of trade expands, the link between developing countries and developed countries will be further strengthened. Intermediate products create the link between producers of different components dispersed across the globe. The proportion of imports and exports of intermediate products in total imports and exports is selected as the control variable.

We have used various macro-economic data to do the analysis on the positioning of the ICT industry in the GVC. We assume non-linear relationships among the variables. Usually, nonlinear regression is used to estimate the parameters in a nonlinear model. In this case, the usual assumption about the normality of the residuals is not needed. Instead, the main assumption needed is that the data might be well represented by the model. The nonlinear model produces a nonzero difference-in-difference (DD) estimate even without an interaction term. That is, the portion of the DD effect that the author [38] noted should be held constant when evaluating the DD version of interactions in nonlinear models. We assume also host country fixed effects, origin country fixed effects, and industry fixed effects.

\section{Results and Discussion}

\section{Findings of the Study and Discussions}

Table 2 shows the regression results of the impact of sustainable production clauses in the IIAs on the positioning of the ICT industry in the GVC. Columns (1) and (2) present the effects of sustainable production intensity clauses on the economic and physical positioning of the ICT industry in the GVC, respectively. We have added bilateral direct investments, namely FDI and outward direct investment (ODI). The results show that the impact coefficient of sustainable production intensity clauses on the economic location is positive and significant at the $5 \%$ level. That means the sustainable production clauses increase the participation level of ICT firms in the GVC. Sustainable production clauses improve reputation risk management (RRM) as well as reduce risks. They improve the production eco-systems and attract quality FDI along with other know-how. The findings corroborate with the findings of authors $[39,40]$. The impact on the physical position is also positive and significant when $p<0.01$. Sustainable production intensity clauses have a positive impact on the positioning in the GVC of the ICT industry. Sustainable production clauses drive the ICT industry to participate more and in a higher value-added activity into the GVC and create a network of best performers. The regression coefficients of the FDI stock and inflow of FDI are all positive and significant. This finding indicates that the increase in bilateral direct investment inflows between an economy and its economic partners has improved the economic positioning of the ICT industry in the GVC. Accelerated FDI increases 
local sourcing and helps to transfer advanced technologies and knowledge. This kind of inflow takes place more on the upstream activities directly and indirect impacts take place on downstream activities in the mid-to-long term. The Kersan-Škabić (2017) study ([4] supports this finding. More FDI inflows drive firms to participate in more activities in the GVC and increase local sourcing by foreign manufacturers. To reduce procurement costs in the developing markets, MNCs in the GVC do transfer new technology and advanced management practices, technical human capital, knowledge, and business contacts in the global markets to the host country suppliers. These supports help suppliers to increase their productivity, capability, and entry to the international market. Additionally, MNC clients support suppliers from developing countries through technology spill-over effects and lower barriers to knowledge transfer. Though, MNCs keep the higher value-added production activities in their home country and transfer non-core and near core functions, general services, and production links to emerging/developing countries. Still, the continuous knowledge transfer, technical support, and experience of working together can help suppliers to become specialized in the segments of value chains where they have competitive advantages, and gradually capture the higher value-added activities. However, in some cases, MNCs client firms do not collaborate with their suppliers and try to block the knowledge and skills transfer to them in developing countries. They prevent the host country's suppliers from upgrading in the value chain and protect their superior capability and block future competitors. Therefore, the role of MNCs in embedding host country enterprises into the GVCs is relatively complicated.

Table 2. Regression results.

\begin{tabular}{|c|c|c|c|c|}
\hline & (1) & (2) & (3) & (4) \\
\hline SDE & $0.0251(1.6328)$ & $0.0327^{* * *}(0.7382)$ & $0.0172(0.699)$ & $0.0183^{* *}(1.3284)$ \\
\hline FDI & $0.06698^{* * *}(0.0108)$ & $0.0396^{* * *}(1.2935)$ & $0.1303^{* * *}(1.637)$ & $0.0882^{* * *}(1.2834)$ \\
\hline ODI & $0.048(0.0192)$ & $0.0118(1.0745)$ & $0.072 *(0.1932)$ & $0.0837(0.3874)$ \\
\hline MSIZ & & & $0.254^{* * *}(0.2846)$ & $0.224^{* *}(2.3584)$ \\
\hline DGI & & & $0.0894^{* *}(1.0135)$ & $0.0938 * *(0.6414)$ \\
\hline BOUN & & & $0.0732(3.2847)$ & $0.0933(1.0935)$ \\
\hline LANG & & & $0.0384(0.9375)$ & $0.0262(0.84753)$ \\
\hline DIST & & & $-0.3761^{* * *}(0.8309)$ & $-0.4213^{* * *}(0.475)$ \\
\hline R\&D & & & $0.1623^{* * *}(0.2648)$ & $0.1847^{* * *}(0.8374)$ \\
\hline HUM & & & $0.1274^{* * *}(0.6472)$ & $0.1019^{* * *}(1.7362)$ \\
\hline IPIE & & & $0.0719^{* *}(0.8490)$ & $0.0849^{* * *}(0.6949)$ \\
\hline Year fixed effect & $n$ & $n$ & $\mathrm{Y}$ & $\mathrm{Y}$ \\
\hline Country fixed effect & $n$ & $n$ & $\mathrm{Y}$ & $\mathrm{Y}$ \\
\hline$n$ & 2362 & 2362 & 2362 & 2362 \\
\hline $\mathrm{R}^{2}$ & 0.3827 & 0.3385 & 0.6538 & 0.7023 \\
\hline
\end{tabular}

Note: $* * * * *{ }^{*}$ represents $p<0.01, p<0.05, p<0.1$, respectively.

The impact of the outflow of direct investment (ODI) is not significant. On the one hand, the expansion of ODI will lead to the relocation of domestic industries, reducing the share of domestic exports and the added value of exports. There is a substitute relationship between exports and outward foreign investment. Conversely, if the country can achieve industrial upgrading with the support from the lead firms and a continuous transfer of the midstream and upstream manufacturing activities to other suppliers, then the physical position of the GVC can be improved by focusing on the downstream higher value-added activities in the GVC, and keep the focus on production processes close to the final demand, and contribute to the specialization. The findings corroborate with the results from the study conducted by [11] Van der Marel (2015).

Columns (3) and (4) show the results of the tests related to the impact of sustainable production intensity clauses on the economic and physical position of the ICT industry in the GVC after adding the gravitational equation and control variables. The impact of sustainable production intensity clauses is the same as in columns (1) and (2). In the 
dummy variables, the two economies have a common boundary (BOUN) and language (LANG), and the influence coefficient on the position of an economy participating in the GVC is positive, but not significant, regardless of the economic or physical positions. The regression coefficients of the distance variable (DIST) are all significantly negative. The increase in the distance between economies is not favorable to increasing the scale of participation of the ICT industry in the GVC. The regression coefficients of the market size (MSIZ) variables are all significantly positive, indicating that the larger the market size between an economy and its partners, the more beneficial it is to increase the economy's participation in the GVC of the ICT industry. In other words, larger economies participate in more production processes in GVCs. The regression coefficient of the institutional scale variable is positive and significant at the $5 \%$ level, indicating that the higher the governance quality of an economy, the greater the influence on the positioning of participation in the GVC. Well-established institutional infrastructure and good governance positively impact the participation and positioning in the GVC.

Missing variables and two-way causality are the main causes of endogenous problems. The first thing that needs to be explained is that the endogeneity problem in this article is relatively weak. This article considers major macro-economic variables that affect the positioning in the GVCs, such as geographic distance, boundaries, common language, R\&D investment, human capital, and intermediate product imports and exports, and also controls the year-fixed effect and country-fixed effect to alleviate the problem of missing variables. However, the location in the GVC will also adversely affect the bilateral investment agreement, coupled with the endogenous problems caused by potential missing variables, which may lead to biased estimates. Referring to the authors [41], legal origin classification method, and using the legal source as an instrumental variable to solve the problem of missing variables that may affect both bilateral investment agreements and the location in GVCs, the main considerations are as follows: As an exogenous variable, the source of law does not directly affect the status of a country's value chain, nor does it directly affect the upstream and positioning in the GVC. However, good legal protection will help the economic development of the region and also promote bilateral investment agreements, columns (1) to (2) of Table 3 respectively report the estimation results of the two-stage least squares (2SLS) method with the source as an instrumental variable. At the same time, this article uses a variety of statistical tests to determine the validity: KleibergenPaap rk LM, Kleibergen-Paap Wald rk F, Anderson-Rubin Wald, and Stock-Wright LM S Wald statistics. All the test results show rejection of the null hypothesis, indicating the effectiveness of instrumental variables. After using the instrumental variable method, we found that the conclusions are still robust, and the core explanatory variable coefficients are still significantly positive, that is, the sustainable production clauses of the bilateral investment agreement positively and significantly affect the positioning of a country's ICT global value chain.

In the process of transnational operations, MNCs organize their activities based on the global division of labor in the GVC according to the degree of economic development of each participating country. Therefore, we classify countries with bilateral investment agreements between developed countries, between developed and developing countries, and between developing countries, to verify the impact of sustainable production clauses on the positioning of the ICT industry in the GVC.

Table 4 outlines the impact of the sustainable production intensity clauses in different types of IIAs on the position in the GVC.

In Table 4, columns (1) and (2) show the influence of the sustainable production intensity clauses of bilateral investment agreements between the developed countries on the positioning of the ICT industry in the GVC. Although the influence is positive, it is not significant. This is mainly because developed countries attach great importance to sustainable production and an environment-friendly business ecosystem. They already have institutional infrastructures for sustainable business practices regardless of having such clauses in the IIAs. Even if there is no explicit mention of sustainable production and 
responsible business conducts in the IIAs, MNCs in the developed markets need to abide by the local strict rules and regulations on sustainability and corporate social responsibilities. Therefore, bilateral investment agreements do not have significant effects on positioning in the GVC.

Table 3. Heterogeneity test and differentiated effects on developing vs. developed markets.

\begin{tabular}{ccc}
\hline Instrumental Variable & $\mathbf{( 1 )}$ & $\mathbf{( 2 )}$ \\
\hline SDE & $0.0182(1.027)$ & $0.0127^{*}(0.5629)$ \\
Kleibergen-Paap Wald rk LM & 17.92 & 17.92 \\
& {$[0.00]$} & {$[0.00]$} \\
Kleibergen-Paap Wald rk F & 20.22 & 20.22 \\
& {$[16.38]$} & {$[16.38]$} \\
Anderson-Rubin Wald & 12.37 & 14.58 \\
& {$[0.003]$} & {$[0.002]$} \\
Stock-Wright LM S Wald & 13.16 & 15.22 \\
Year fixed effect & {$[0.002]$} & {$[0.004]$} \\
Country fixed effect & $\mathrm{Y}$ & $\mathrm{Y}$ \\
$n$ & $\mathrm{Y}$ & $\mathrm{Y}$ \\
$\mathrm{R}^{2}$ & 2362 & 2362 \\
F statistics & 0.6873 & 0.7219 \\
& 13.42 & 10.58 \\
\hline
\end{tabular}

Note: ${ }^{*}$ represents $p<0.1$.

Table 4. Sustainable development intensity on the GVC position.

\begin{tabular}{|c|c|c|c|c|c|c|}
\hline & (1) & (2) & (3) & (4) & (5) & (6) \\
\hline \multirow{2}{*}{ SDE } & 0.06801 & 0.0294 & $0.0554 * *$ & $0.05193^{* * *}$ & 0.0382 & 0.0328 \\
\hline & $(0.763)$ & $(1.0283)$ & $(0.2736)$ & (1.0281) & $(0.385)$ & (1.9023) \\
\hline \multirow{2}{*}{ FDI } & $0.2194^{* * *}$ & $0.2806^{* * *}$ & $0.2017^{* * *}$ & $0.2264^{* *}$ & $0.2437^{* * *}$ & $0.2372^{* * *}$ \\
\hline & (1.0873) & (0.83728) & $(4.2778)$ & $(3.0283)$ & (1.0388) & (3.029) \\
\hline \multirow{2}{*}{ ODI } & $0.0829 * *$ & $0.0718^{* * *}$ & $0.0829^{* * *}$ & $0.1081^{* *}$ & $0.1219^{* * *}$ & 0.1321 * \\
\hline & $(1.0831)$ & $(1.0273)$ & (1.873) & $(3.9278)$ & $(4.374)$ & $(1.394)$ \\
\hline \multirow{2}{*}{ MSIZ } & $0.1782^{* *}$ & $0.1029^{* * *}$ & $0.1327^{* *}$ & $0.0922 *$ & $0.1023^{* *}$ & $0.0821 * *$ \\
\hline & (1.8392) & $(1.7369)$ & $(0.8257)$ & $(2.0927)$ & $(0.372)$ & $(2.0928)$ \\
\hline \multirow{2}{*}{ DGI } & $0.06384^{* *}$ & $0.0706^{* * *}$ & 0.0827 & 0.0821 & 0.0527 & 0.039 \\
\hline & $(1.7858)$ & (3.0829) & (1.0299) & $(0.0292)$ & $(0.2793)$ & $(0.1938)$ \\
\hline \multirow{2}{*}{ BOUN } & 0.0129 & 0.0201 & 0.0192 & 0.0022 & 0.0138 & 0.0022 \\
\hline & $(0.7221)$ & $(0.2839)$ & (1.0837) & $(0.0285)$ & $(0.2242)$ & $(0.274)$ \\
\hline \multirow{2}{*}{ LANG } & 0.0020 & 0.0017 & 0.0021 & 0.0018 & 0.013 & 0.0021 \\
\hline & (1.3774) & $(0.0263)$ & $(0.2934)$ & (1.0273) & $(0.2738)$ & $(0.3745)$ \\
\hline \multirow{2}{*}{ DIST } & $-0.0328^{* *}$ & $-0.0277^{*}$ & $-0.0289 * * *$ & $-0.0279 *$ & $-0.0736 *$ & -0.0113 \\
\hline & (2.283) & $(1.2366)$ & (1283) & (1.374) & $(-2.8741)$ & $(0.0391)$ \\
\hline \multirow{2}{*}{ R\&D } & $0.1723^{* * *}$ & $0.1690^{* * *}$ & $0.1492^{* * *}$ & $0.1573^{* *}$ & $0.1726^{* * *}$ & $0.1826^{* * *}$ \\
\hline & $(0.0347)$ & $(0.2736)$ & $(0.0283)$ & $(0.0287)$ & $(3.9750)$ & $(3.2038)$ \\
\hline \multirow{2}{*}{ HUM } & $0.10288^{* * *}$ & $0.0927^{* * *}$ & $0.1374^{* *}$ & $0.0728^{* * *}$ & $0.0837^{* * *}$ & $0.1027^{* * *}$ \\
\hline & (1.3859) & $(0.7287)$ & $(1.2774)$ & (1.809) & $(2.3084)$ & $(0.2847)$ \\
\hline \multirow{2}{*}{ IPIE } & $0.08371^{* * *}$ & $0.1025 * *$ & $0.1237^{* * *}$ & $0.1135^{* *}$ & $0.1538^{* * *}$ & $0.1326^{* * *}$ \\
\hline & (1.0937) & $(2.3849)$ & $(0.0921)$ & $(2.3864)$ & $(0.3875)$ & $(0.8468)$ \\
\hline Year fixed effect & $\mathrm{Y}$ & $\mathrm{Y}$ & $\mathrm{Y}$ & $\mathrm{Y}$ & $\mathrm{Y}$ & $\mathrm{Y}$ \\
\hline Country fixed effect & $\mathrm{Y}$ & $\mathrm{Y}$ & $\mathrm{Y}$ & $\mathrm{Y}$ & $\mathrm{Y}$ & $\mathrm{Y}$ \\
\hline$n$ & 426 & 426 & 1631 & 1631 & 305 & 305 \\
\hline $\mathrm{R}^{2}$ & 0.6827 & 0.6399 & 0.7212 & 0.669 & 0.7024 & 0.6938 \\
\hline
\end{tabular}

Note: ${ }^{* * *},{ }^{* *},{ }^{*}$ represent $p<0.01, p<0.05, p<0.1$, respectively.

Columns (3) and (4) show the impact of the sustainable production intensity clauses of bilateral investment agreements between developed and developing countries on the position of the ICT industry in the GVC. Regardless of the economic or physical position, the impact of sustainable production intensity clauses on the GVC is positive and significant 
at the $1 \%$ level, indicating that the intensity of sustainable production and responsible business practices affect the behavior of MNCs in the developing markets. Sustainable production principles in the IIAs affect the international division of labor among participating developed and developing countries. Through direct investment in developing countries, MNCs can move from a low value-added activity on the industrial chain to the middle and upper value-added activities and expand the added value of products. For developing countries, the sustainable production provisions guide the behavior of MNCs and continuously improve the level of economic governance and business environment as well as corporate social responsibility compliances. The improved economic governance attracts more high-tech MNCs with quality FDI to invest in higher value-added activities, thereby, improving the physical and economic position of the ICT industry from the developing countries on the GVC. Sustainable production intensity clauses in the IIAs might influence the ICT industry in developing countries to move from the pollution embedded low-cost labor-intensive activities to higher value-added value chain/s from the manufacturing bottom stream to the top of the upstream or to the downstream in the long term.

Columns (5) and (6) show the effects of bilateral investment agreements between developing countries. Since there are relatively few regulations on sustainable production principles in developing markets, there are more sustainable production provisions in bilateral investment agreements. Between the developing markets, bilateral investment agreements account for a relatively small proportion. Therefore, the regression results show that the intensity of sustainable production clauses has a small and insignificant impact on the positioning of the bilateral ICT industry in the GVC.

In summary, the regression results show that the sustainable production intensity clauses of IIAs will improve the overall participation of the ICT firms from the developing markets on the GVC. The impact on the economic position is positive and significant, and the impact on physical positions is positive but insignificant. One of the reasons why we have "insignificant" impact of sustainability clauses on the physical positioning of ICT in the GVC can be due to the slow pace of transformation of production processes. Developing a production eco-system with advanced technology, human capital, skills, and competence, as well as relevant institutions takes time. A longitudinal study might be able to capture the transformation processes from the low value-added manufacturing towards higher value-added activities in the GVC. There are several examples of such transformations of emerging countries such as South Korea, Singapore, and China that have moved from low tech pollution embedded production towards high tech production and continuously captured higher value-added activities in the GVC.

Analysis of heterogeneity shows that the intensity of sustainable production clauses in the IIAs has different effects on different countries depending on the level of economic development. Although the sustainable production intensity clauses in the IIAs among the developed countries have a positive impact on the positioning in the GVC, it is not significant. The impact of sustainable production clauses in bilateral investment agreements between developed and developing countries on the location of the ICT industry in the GVC is positive and significant, regardless of whether it is an economic or physical location. The sustainable production clauses in bilateral investment agreements signed by developing countries do not have a significant effect on the positioning in the GVCs. The findings imply that the sustainable production and responsible business practice clauses in the IIAs can enhance the participation of the developing country ICT firms in the GVC and improve their dynamic capabilities. As in most cases, the global production network (GPN) or regional production network (RPN) is formed between the firms from the developed and developing markets under the GVC framework. This is different from the general views that higher requirements of sustainability compliance deter FDI in developing countries. Our study also shows that sustainable production clauses in the IIAs between developed and developing countries are more effective. This is because there are heterogeneous resources and expertise among the partner firms which offer the opportunity of knowledge sharing and exchanges of each other's comparative and competitive advantages. 


\section{Conclusions}

The GVC can increase incomes, create better jobs, and economic prosperity. A high degree of specialization can improve efficiency, productivity, and innovation. Lasting inter-firm relationships can contribute to knowledge transfer and enhance the capability of supplier firms in the value chain. Participation in the GVC creates more value to the local economy than traditional trade. In addition, the change in the physical location of a country's export product structure from primary products to high-value-added industrial products has the greatest impact. Countries all over the world hope to transform from the processing and assembly links of the GVC to high value-added links such as research and development, product conception and design, prototype development, and to achieve high value-adding positioning in the GVC. However, the development of GVCs can have some undesirable effects on labor markets, the environment, and society. Policy-makers, business leaders, and civil society need to develop adequate policy support to overcome those challenges and participate in the GVC to reap the advantages that this framework offers. A country's foreign trade policy must consider how to attenuate harmful effects on society and maximize economic benefits. Countries should pay attention to sustainable development by participating in GVCs that conform to the triple bottom line of sustainable development. Countries can enjoy business benefits from joining the GVC and avoid the "race to the bottom approaches" on labor and environmental standards [42]. In other words, while participating in the development of the GVC economy, countries must consider long-term social, economic, and environmental issues. Developing countries with lower economic status have lower bargaining power. They can impose favorable conditions through the sustainable production clauses in IIAs while participating in GVCs. The novelty of our study is to demonstrate that by integrating sustainable production principles into the strategy of the organizational governance process, participating firms can improve the positioning in the GVC by moving towards higher value-added activities. This has also proved that sustainable production principles can have real economic benefits on top of reputation and image-related benefits. It shows also that not only the internal firm-level processes but also the external business environment can contribute to moving towards cleaner production and sustainability.

We have empirically tested the impact of sustainable production intensity clauses on the positioning of a country's ICT industry in the GVC. First of all, the sustainable production intensity clauses in the IIA will elevate the positioning of a country's ICT in the GVC. We distinguish between the physical location and economic location in the GVC. The sustainable production intensity clauses in the IIAs have positive impacts on these two statuses. This shows that the sustainable development clauses in the IIAs will affect a country's participation in the GVC, and will shift towards cleaner processes and production links. The finding implies that the sustainable production intensity clauses positively favor the transition to better positioning in the GVC of participating firms. Second, we distinguish between IIAs signed between different types of countries; including between developed countries, between developed countries and developing countries, and between developing countries. The empirical results of these three types of IIAs show that the sustainable production intensity of the bilateral investment agreement signed between developed and developing countries can help improve the positioning of developing countries in the GVC, and the sustainable production intensity of other types of IIA has no significant impact on the positioning.

Overall, the sustainable production clauses in the IIAs have a positive impact on positioning in the GVC. Therefore, in the era of GVCs, countries must actively participate in the GVC if they want to continuously achieve industrial upgrading and high-value-added GVC positioning. For developing countries, this means implementing a more open policy, increasing the intensity of opening to the outside world, deepening reforms, strengthening society and environmental protection, improving institutions and implementing good governance, and signing more investment agreements. Industrialized countries must pursue a more open and stable global trade policy focusing on the GVC by integrating 
emerging and developing countries that ensure shared sustainable prosperity. The benefits of participating in the GVC can be shared and sustained. Our findings can be helpful for both managers and policy-makers to develop effective strategies in participating in the GVC and accelerate socio-economic development. Future research can address the decomposition of types of activities within the GVC such as low-tech, mid-tech, and high-tech and evaluate their respective impacts on positioning in the GVC.

Author Contributions: Conceptualization, Q.M., M.M. and Y.C.; methodology, Q.M.; software, Q.M.; validation, Q.M., M.M. and Y.C.; formal analysis, Q.M., M.M. and Y.C.; investigation, Q.M., M.M.; resources, Q.M., M.M. and Y.C.; data curation, Q.M.; writing—original draft preparation, Q.M. and M.M.; writing-review and editing, Q.M., M.M. and Y.C.; visualization, Q.M., M.M. and Y.C.; supervision, Y.C.; project administration, Q.M.; funding acquisition, Q.M. All authors have read and agreed to the published version of the manuscript.

Funding: The soft science project of Zhejiang Province "Research on the reconstruction of global value chain and high quality industrial cluster: the global value chain perspective of chain master system". Project Number: 2021C25039.

Data Availability Statement: CDIs (coordinated direct investment survey), International Monetary Fund, Washington DC, USA. link: https:/ / data.imf.org/?sk=40313609-F037-48C1-84B1-E1F1CE54D6 D5, accessed on 9 August 2021.

Conflicts of Interest: The authors declare no conflict of interest.

\section{References}

1. Fernandez-Stark, K.; Gereffi, G. Global value chain analysis: A primer. In Handbook on Global Value Chains; Edward Elgar Publishing: Cheltenham, UK, 2019.

2. Shih, S. Reconstitution of Acer: Start-up, Growth and Challenge, 2nd ed.; Taipei Commonwealth Publishing: Taipei, Taiwan, 1992. (In Chinese)

3. Mohiuddin, M.; Su, Z. Global value chains and the competitiveness of Canadian manufacturing SMEs. Acad. Taiwan Bus. Manag. Rev. 2014, 10, 82-92.

4. Kersan-Škabić, I. Assessment of EU member states' positions in Global Value Chains. East. J. Eur. Stud. 2017, 8, 5-24.

5. Albors-Garrigos, J.; de Miguel Molina, B.; de Miguel Molina, M. Positioning in the global value chain as a sustainable strategy: A case study in a mature industry. Adm. Sci. 2014, 4, 155-172. [CrossRef]

6. Amendolagine, V.; Presbitero, A.F.; Rabellotti, R.; Sanfilippo, M. Local sourcing in developing countries: The role of foreign direct investments and global value chains. World Dev. 2019, 113, 73-88. [CrossRef]

7. Mohiuddin, M.; Su, Z. Manufacturing small and medium size enterprises offshore outsourcing and competitive advantage: An exploratory study on Canadian offshoring manufacturing SMEs. J. Appl. Bus. Res. 2013, 29, 1111-1130. [CrossRef]

8. Ustyuzhanina, E.V.; Evsukov, S.G.; Ustyuzhanin, V.L.; Novikova, E.S. The distribution of economic rent within global value chains in resource management. Int. J. Supply Chain. Manag. 2019, 8, 1018-1026.

9. Antràs, P.; De Gortari, A. On the geography of global value chains. Econometrica 2020, 88, 1553-1598. [CrossRef]

10. Baldwin, R.; Ito, T.; Sato, H. The Smile Curve: Evolving Sources of Value Added in Manufacturing; Joint Research Program Series; Institute of Developing Economies-Japan External Trade Organization: Chiba City, Japan, 2014.

11. Van der Marel, E. Positioning on the global value chain map: Where do you want to be? J. World Trade 2015, 49, 915-949.

12. Antràs, P.; Chor, D. On the Measurement of Upstreamness and Downstreamness in Global Value Chains; Routledge Publications: Oxen, UK, 2018; pp. 126-194.

13. Gereffi, G. Global Value Chains and Development: Redefining the Contours of 21st Century Capitalism; Cambridge University Press: Cambridge, UK, 2018.

14. Colen, L.; Persyn, D.; Guariso, A. Bilateral Investment Treaties and FDI: Does the Sector Matter? World Dev. 2016, 83, 193-206. [CrossRef]

15. Jayashree, S.; Reza, M.N.H.; Malarvizhi, C.A.N.; Mohiuddin, M. Industry 4.0 implementation and Triple Bottom Line sustainability: An empirical study on small and medium manufacturing firms. Heliyon 2021, 7, e07753. [CrossRef] [PubMed]

16. Mohiuddin, M.; Hosseini, E.; Faradonbeh, S.B.; Sabokro, M. Achieving Human Resource Management Sustainability in Universities. Int. J. Environ. Res. Public Health 2022, 19, 928. [CrossRef] [PubMed]

17. Lederman, D.; Maloney, W.; Serven, L. Lessons from NAFTA for Latin America and Caribbean Countries: A Summary of Research Findings; World Bank: Washington, DC, USA, 2005.

18. Nemati, M.; Hu, W. Are Free Trade Agreements Goods for the Environment? A panel Data Analysis. Rev. Dev. Econ. 2019, 23, 433-453. [CrossRef]

19. Cingolani, I.; Panzarasa, P.; Tajoli, L. Countries' positions in the international global value networks: Centrality and economic performance. Appl. Netw. Sci. 2017, 2, 1-20. [CrossRef] 
20. World Bank. World Development Report 2020: Trading for Development in the Age of Global Value Chains. 2020. Available online: https:/ / www.worldbank.org/en/publication/wdr2020 (accessed on 15 November 2021).

21. WCED (The World Commission on Environment and Development). Our Common Future; Oxford University Press: Oxford, UK, 1987.

22. Tsalis, T.A.; Malamateniou, K.E.; Koulouriotis, D.; Nikolaou, I.E. New challenges for corporate sustainability reporting: United Nations' 2030 Agenda for sustainable development and the sustainable development goals. Corp. Soc. Responsib. Environ. Manag. 2020, 27, 1617-1629. [CrossRef]

23. Bodansky, D. The Paris climate change agreement: A new hope? Am. J. Int. Law 2016, 110, 288-319. [CrossRef]

24. Cruz, L.B.; Boehe, D.M. CSR in the global marketplace: Towards sustainable global value chains. Manag. Decis. 2008, 46, 1187-1209. [CrossRef]

25. Alhawari, O.; Awan, U.; Bhutta, M.K.S.; Ülkü, M.A. Insights from circular economy literature: A review of extant definitions and unravelling paths to future research. Sustainability 2021, 13, 859. [CrossRef]

26. Gordon, K.; Pohl, J.; Bouchard, M. Investment Treaty Law, Sustainable Development and Responsible Business Conduct: A Fact-Finding Survey; OECD Working Papers on International Investment; OECD: Paris, France, 2014.

27. de Oliveira Neto, G.C.; Correia, J.M.F.; Silva, P.C.; de Oliveira Sanches, A.G.; Lucato, W.C. Cleaner Production in the textile industry and its relationship to sustainable development goals. J. Clean. Prod. 2019, 228, 1514-1525. [CrossRef]

28. Wu, G.C. Effects of socially responsible supplier development and sustainability-oriented innovation on sustainable development: Empirical evidence from SMEs. Corp. Soc. Responsib. Environ. Manag. 2017, 24, 661-675. [CrossRef]

29. Wang, Y.; Yang, Y. Analyzing the green innovation practices based on sustainability performance indicators: A Chinese manufacturing industry case. Environ. Sci. Pollut. Res. 2021, 28, 1181-1203. [CrossRef]

30. OECD. G20/OECD Principles of Corporate Governance; OECD Publishing: Paris, France, 2015.

31. Prabhash, R. How 'Healthy' are the Investment Treaties of South Asian Countries: An Empirical Study of Public Health Provisions in South Asian Countries' BITs and FTA Investment Chapters. Foreign Investig. Law J. 2018, 33, 213-242.

32. Said, F.F.; Fang, M. A probe into the status of global countries' trade positions in the global value chain (GVC)-based on value added trade perspective and network modeling. Eur. J. Sustain. Dev. 2019, 8, 305. [CrossRef]

33. Salo, J. The Impact of Cross-Border Investments on Economic Growth in ASEAN. 2020. Available online: http://urn.fi/URN: NBN:fi-fe202001243393 (accessed on 15 November 2021).

34. Koopman, R.; Wang, Z.; Wei, S.-J. Tracing Value-added and Double Counting in Gross Exports. Am. Econ. Rev. 2014, 104, 459-494. [CrossRef]

35. Fally, T. On the Fragmentation of Production in the US; University of Colorado: Boulder, CO, USA, 2012 ; pp. 1-49.

36. Antràs, P.; Chor, D.; Fally, T.; Hillberry, R. Measuring the Upstream-ness of Production and Trade Flows. Am. Econ. Rev. 2012, 3 , 412-416. [CrossRef]

37. Brach, J.; Kappel, R.T. Global Value Chains, Technology Transfer and Local Firm Upgrading in Non-OECD Countries; GIGA Working Paper: Hamburg, Germany, 2009.

38. Puhani, P.A. The Treatment Effect, the Cross Difference, and the Interaction Term in Non-Linear 'Difference-in-Differences' Models Discussion Paper Series: Forschungsinstitut zur Zukunft der Arbeit, Institute for the Study of Labor (April 2008 ). 2008. Available online: http:/ /ftp.iza.org/dp3478.pdf (accessed on 9 August 2011).

39. Louche, C.; Idowu, S. (Eds.) Innovative Csr: From Risk Management to Value Creation; Routledge Publications: Oxon, UK, 2017.

40. Bebbington, J.; Larrinaga, C.; Moneva, J.M. Corporate social reporting and reputation risk management. Account. Audit. Account. J. 2008, 21, 337-361. [CrossRef]

41. Porta, R.L.; Lopez-de-Silanes, F.; Shleifer, A.; Vishny, R.W. Law and finance. J. Political Econ. 1998, 106, 1113-1155. [CrossRef]

42. Taylor, L.; Ömer, Ö. Race to the bottom: Low productivity, market power, and lagging wages. Int. J. Political Econ. 2019, 48, 1-20. [CrossRef] 